\title{
黒毛和種牛における新生子虚弱の発生と 母体内発育遅延に関する研究
}

\author{
小形芳美* \\ 山形県農業共済組合連合会＼cjkstart置賜家畜診療所
}

\begin{abstract}
Intrauterine Growth Retardation as a Cause of Perinatal Mortality in Japanese Black Calves.
\end{abstract}

\author{
Yoshimi Ogata* \\ Okitama Large Animal Clinic of Yamagata NOSAI
}

要 約 黒毛和種子牛の周産期死亡に関する詳細な疫学的調查を実施するとともに、死亡原因のうち 最も多くを占めている新生子虚弱について、その病態を把握し、対策を講じることを目的に、一連の試 験を実施した。出生子牛 6,475 頭に扔ける周産期死亡率は $4.5 \%$ にのほり、最も主要な原因は新生子虚弱 であった。虚弱新生子は妊娠期間が正常であるにもかかわらず、発育下限值を下回る IUGR 例が多く、 死亡例では70\%以上を占めた。これらの新生子の多くでは筫血が認められ、骨䯣の低形成が確認された。 また、母牛の妊娠末期における $\mathrm{E}_{1} \mathrm{~S}$ 濃度が低く、新生子虚弱の原因のひとつとして胎子一胎盤機能の 低下が示唆された。

一キーワード：新生子虚弱、母体内発育遅延、貧血、胎盤機能、周産期死亡

東北家畜臨床研誌 $22 \quad(2): 43-50,1999$

ABSTRACT Perinatal death is one of the major causes of calf mortality in Japanese Black beef herds. A series of experiments were carried out to determine causes of perinatal calf mortality in a region of northern Japan. An aetiological survey revealed that the incidence of perinatal calf mortality in 6,475 calves was $4.5 \%$ and the majority of neonatal deaths were caused by weak calf syndrome. The weak calves delivered after a normal gestation period had a significantly lower body weight at birth than normal calves $(\mathrm{P}<0.01)$, indicating growth retardation in the uterus during pregnancy. Haematological and histopathological examinations showed that the weak calves had anaemia characterized by a significant decrease of blood cell values and bone marrow hypofunction. The anaemia due to bone marrow hypofunction presumably caused intrauterine growth retardation of the foetus. Dams delivering the weak calves showed significantly lower serum concentrations of estrone sulphate during late pregnancy than those with normal calves $(\mathrm{P}<0.01)$, indicating foeto-placental dysfunction as apossible cause of growth retardation. Intrauterine growth retardation associated with anaemiamay be the most important cause of weak calf syndrome in Japanese Black beef calves.

- Key Words: anaemia, foeto-placental dysfunction, intrauterine growth retardation, perinatal death, weak calf syndrome

Tohoku J. Vet. Clin. 22 (2) : 43-50, 1999

*Correspondence to : 3668-3 Kubotamachi, Yonezawa-shi, Yamagata-ken 992-0002, Japan

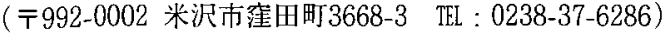




\section{1.はじめに}

周産期における子牛の死亡は、肉用牛の生産性を左右 する最も大きな要因のひとつである。一般に、肉用種子 牛の死亡率は $5 \sim 6 \%$ といわれいる [1] が、Cain 5 [2] は、肉用種子牛の周産期死亡率は8.6\%であった と報告し、Kasari [3] は、生後28日齢までの子牛の死 亡率は 4〜8\%にのぼると報告している。

わが国では、肉用種子牛に㧍ける損耗の実態を調査し た報告は少なく、1986年の農業災害補償法改正を契機に、 胎子と子牛の死亡に関する調查が実施され始めた。山口 と菊川 [15] は、和牛子牛の損耗率は共済加入頭数の約 $4 \%$ にの゙ることを報告し、野口 [4] は、同死亡率は 2 ー 3\%であったと報告している。

子牛の周産期死亡は、生後 7 日以内の新生子に集中し て起こるとされているが、死亡原因を特定できない例が 多く、高橋ら [13]、山口と㐘川 [15］および野口 [4] は、生後 1 週間以内に原因不明で死亡した子牛のうち、 出生直後に仮死状態を呈し、吸乳力の弱い子牛が最も多 くを占めていたと報告しており、原因不明の新生子死亡 の大半は新生子虚弱によるものと推察される。このよう な新生子虚弱の発症要因としては、難産に起因する低酸 素血症 [3] をはじめ、種々の要因が考えられているが、 黒毛和種の虚弱子牛についてはまだ十分には解明されて いない。

そこで、1987年から、黒毛和種子牛の周産期死亡に関 する詳細な疫学的調査を実施するとともに、出生子牛の 死亡原因のうち、最も多くを占めている新生子虚弱につ いて、その病態を把握することを目的に、虚弱子牛の出 生直後の血液学的ならびに生化学的検查を行い、正常な 子牛との比較検討を行った。

さらに、新生子虚弱の発生が、妊娠末期の母牛の栄養 状態や胎子への唯一の栄養供給の部位である胎盤の機能 とどのような関係にあるかを検索した。とくに虚弱子牛 の胎子期における発育障害と、胎子一胎盤機能の低下と の関係について検討を行うとともに虚弱子牛に対する治 療法についても検討を加えた。

\section{2. 周産期子牛の死亡原因と出生時体重}

山形県 $\mathrm{O}$ 地区 $\mathrm{K}$ 町で飼育されている黒毛和種牛におい て、1987年から1993年まで7 年間に出生した6,475頍の 子牛について、すべての周産期死亡の発生状況を調査し た $[5,16]$ 。

1) 周産期子牛の死亡率: 出生子牛 6,475 頭（胎齢240日 以降の死産を含む）のうち、死産は155頭 $(2.4 \%) 、$ 新
生子死亡（生後14日以内）は133頭（2.1\%）であった。 したがって、この間の周産期死亡率は $4.5 \%$ であったが、 年次および月ごとの発生率には差がなかった。

2 ) 死産および新生子死亡の原因 : 臨床所見と病理所見 から死亡原因を確定（121頭剖検）し、初乳未摄取の 32頭については、異常産に関与するウィルスの血清中抗 体価を測定した。

死産例においては、原因不明の症例が最も多く、 $69.7 \%$ (108頭) を占めていた。

新生子死亡例のうち、最も多かったのは、臨床的に明 かな原因が認められないにもかかわらず、活力に乏しく、 自力で起立吸乳ができずに衰弱死したもので、 $59.4 \%$ （79頭）を占めた。これらは新生子虚弱とし、次いで下 症症が $17.3 \%$ (23頭) を占めた。先天異常が認められた ものは 4 頭 $(3.0 \%)$ であり、内訳は球状赤血球症 3 頭 および染色体異常1頭であり（表1）、ウィルスによる異 常産はなかったと判定された。

3 ）死産抢よび新生子死亡の発生に影響する要因 (1)在胎期間：死産例は新生子死亡例より短かった（P<

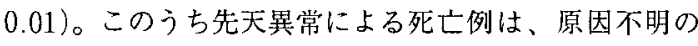
死産例抢よび虚弱による死亡例と比べ、それぞれ有意に 長かった（P<0.01）。

(2)出生時体重 : 出生時体重を死亡原因別にみる上、死産 例のうち原因不明の死産子は、難産によるものと比べ有 意に小さく $(P<0.01)$ 、新生子死亡例のうち虚弱によ るものは、出生後のいわゆる後天的原因による死亡と判 断される下咪症、母牛による損傷、肺炎、臍帯炎および その他の原因により死亡した33頭の平均値 $26.2 \pm 5.9$ （雄 : $26.4 \pm 5.8$ 、雌 : $25.6 \pm 6.0$ ) kgに比べ体重が明らか に低かった $(\mathrm{P}<0.01) 。$

在胎期間と出生時体重との関係を検討したところ、原 因不明の死産例においては、有意な正の相関 $(r=0.48$ 、 $\mathrm{P}<0.01$ ) が認められた（図 1) のに対し、新生子虚弱 による死亡例では有意な相関が認められなかった（図2）。 (3)血統との関連：血統は、すべての出生子牛の種雄牛を 調査し、母系についてはそれぞれの供用頻度が最も高い 3 年間について、5代前まで調査した。また、同時期に 出生した健康な子特284頭を無作為に抽出し、各種雄牛 ごとに発育下限境界値を算出し、死亡子牛における母体 内発育遅延の発生率を調查した。


雄 (144頭 : $28.8 \pm 4.8 \mathrm{~kg}$ ) は雌 (140頭：25.8土3.7 kg) より大きかった $(\mathrm{P}<0.01$ )。在胎期間は285.7土5.5（雄： $286.6 \pm 5.5 、$ 雌 : $284.8 \pm 4.3)$ 日であった。種雄牛別に 
産子の出生時体重および在胎期間を比較すると、在胎期 間は差がなかったが、出生時体重は種雄牛 $\mathrm{M}$ および $\mathrm{Y}$ の産子がその他の種雄牛の産子に比べて低いことが示さ れた $(\mathrm{P}<0.05)$ 。

健康な子牛に扔ける出生時体重の下限境界值として、 平均值から $3 / 2 \sigma(\mathrm{SD})$ を減じた值を用いると、こ の地域では20.4kg（雄：21.3kg、雌 : $19.8 \mathrm{~kg}$ ）であった。 同様に、在胎期間の標準は平均值に $2 \sigma$ を加減し求めた 274.7 296.7日と算出された。そこで、母体内発育遅延 (intra-uterine growth retardation: IUGR) の基 準を、在胎期閒 275 日以上で、出生時体重が $20 \mathrm{~kg}$ 以下の 個体と規定した。死産胎子扔よび死亡した新生子のうち、 IUGRが認められたものは $31.3 \%$ （90頭）を占めた。 その内訳は、虚弱が57頭、原因不明の死産が20頭、先天 異常が 8 頭掞よび下痢症が 5 頭であった。

調査期間中に出生した子牛の父牛として供用された種 雄牛（9頭）をM、Y、O、Tおよびその他の 5 頭に分 けて種雄牛別にみたところ、種雄牛 Mの産子はその他 の 5 頭の種雄牛の産子より新生子虚弱による死亡数が多 かった（P<0.01）。また、IUGRが認められた割合も 種雄牛 $\mathrm{M}$ の産子が $2.3 \%(\mathrm{P}<0.001)$ と最も高く、次い で $\mathrm{Y} の 1.7 \%(\mathrm{P}<0.001)$ および $\mathrm{O} 00.8 \%(\mathrm{P}<0.01)$ であり、その他 5 頭の種雄牛の産子に扔ける発生率 (0.3\%) に比べて高かった。

母牛（3,018頭）を系統別にみると、IUGR が認めら
れ死亡した虚弱子牛40頭（1.3\%）中、S系の産子は 28 頭 (28/1,872頭 : $1.5 \%)$ であり、その他の系統の12頭 (12/1,146頭：1.0\%)に比べ多い傾向であった。S系 におけるIUGRの発生率を、それぞれの種雄牛別に比 較したところ、M を交配した場合が最も高く $(4.0 \%) 、$ その他の種雄牛を交配した場合 $(0.9 \%)$ に比べ明らか に高かった $(\mathrm{P}<0.05)[10]$ 。

以上の結果、子牛死亡の発生と出生時体重との間には 密接な関係が存在することが明らかになった。IUGR が認められた症例は、全死亡子牛の $30 \%$ を回り、虚弱 による死亡例では70\%以上を占めていたことから、胎子 期の発育障害が全体の死亡率を引き上げている可能性の あることが示唆された。虚弱による死亡例に扔いては、 在胎期間と出生時体重との相関が認められず、在胎期間 も正常なことから、胎子期に母体との栄盖授受に何らか の障害が存在している可能性が示唆された。

\section{3. 虚弱新生子の病態と母牛の栄養状態}

1991年11月から1994年10月までの3 年間に分婏した、 黒毛和種雌牛 43 頭とその出生子牛を用い、分婏予定日の 4 週間前と 2 週間前に血液学的および生化学的検查を実 施した [8]。また、Wildmanら [14］の方法により母 牛の BCSを計測するとともに、TDN および CP それ ぞれの充足率を求めた。

1 ) 子牛の出生状況: 臨床的に正常な子牛 (正常群) は

表 1. 黒毛和種子牛における死産子および死亡新生子の出生時体重、死亡日齢および在胎期間

\begin{tabular}{|c|c|c|c|c|}
\hline & & 体重（kg）（n） & 死亡月齢(日)(n) & 在胎期間 (日) (n) \\
\hline \multirow[t]{5}{*}{ 産 } & 原因不明 & $19.2 \pm 7.5^{\mathrm{a}}(104)$ & - & $271.4 \pm 16.5^{\mathrm{g}}(108)$ \\
\hline & 難産 & $28.4 \pm 6.0^{b}(29)$ & - & $281.4 \pm 10.6(33)$ \\
\hline & 母牛の死亡 & $-(0)$ & - & $259.3 \pm 11.2(8)$ \\
\hline & 先天異常 & $16.3 \pm 8.7(6)$ & - & $281.5 \pm 6.2^{\mathrm{h}}(6)$ \\
\hline & 計 & $21.0 \pm 8.2(139)$ & - & $273.5 \pm 15.9^{e}(155)$ \\
\hline \multirow[t]{9}{*}{ 新生子死亡 } & 虚 弱 & $19.7 \pm 6.8^{\circ}(73)$ & $2.2 \pm 2.1(79)$ & $283.7 \pm 11.3^{i}(79)$ \\
\hline & 下痢 症 & $23.3 \pm 5.9(15)$ & $8.7 \pm 3.3(23)$ & $282.7 \pm 5.0(23)$ \\
\hline & 母牛による損傷 & $25.8 \pm 2.6(5)$ & $3.3 \pm 2.2(6)$ & $281.2 \pm 4.6(6)$ \\
\hline & 肺炎 & $31.7 \pm 2.4^{\mathrm{d}}(3)$ & $6.4 \pm 5.1(5)$ & $282.8 \pm 7.9(5)$ \\
\hline & 湾 带 炎 & $29.0 \pm 1.0^{\mathrm{d}}(4)$ & $9.0 \pm 2.9(5)$ & $284.8 \pm 6.5(5)$ \\
\hline & 先天異常 & $20.3 \pm 1.1(4)$ & $3.5 \pm 2.1(4)$ & $295.5 \pm 14.7^{j}(4)$ \\
\hline & その他 & $29.2 \pm 6.7^{d}(6)$ & $3.7 \pm 3.5(7)$ & $286.4 \pm 5.8(7)$ \\
\hline & 不明 & $22.0 \pm 2.2(3)$ & $7.3 \pm 3.3(4)$ & $283.8 \pm 3.7(4)$ \\
\hline & 計 & $21.7 \pm 7.0(113)$ & $4.0 \pm 3.8(133)$ & $283.9 \pm 10.0^{t}(133)$ \\
\hline 総 計 & & $21.3 \pm 7.7 \quad(252)$ & $1.9 \pm 3.3(133)$ & $278.3 \pm 14.5(288)$ \\
\hline
\end{tabular}

数值は $\mathrm{M} \pm \mathrm{SD}$ を示守

$a-b, c-d, e-f, g-h, i-j: p<0.01$ 
27頭であった。出生後 1 時間を経過しても起立、吸乳が できない虚弱子牛は12頭で、このうち 6 頭は治癒（虚弱 群）したが、他の6 頭は生後 3 日以内に死亡（死亡群） した。妊娠期間256日以前に分婏した早産例 (早産群) は4頭であった。

2) 母牛の BCSおよび栄養摃取量 : 分婏予定 2 週間前 の BCS は、正常群で $3.3 \pm 0.5$ 、虚弱群で $3.8 \pm 0.6$ 、死亡 群では4.1士0.7であり、正常群に比べ虚弱群（P<0.05） と死亡群 $(\mathrm{P}<0.01)$ では高い值を示した。同時期の 1
日あたりの TDNおよびCP 充足率は、各群間で差はな かった。

3) 血液性状の比較: 出生子牛の赤血球数、 $\mathrm{Ht}$ 值およ び $\mathrm{Hb}$ 濃度は、虚弱群、死亡群および早産群では正常群 に比べ低く、とくに死亡群では著しく低かった（図３）。 しかし、死亡群の舟牛の Ht值および $\mathrm{Hb}$ 濃度は正常群 よりも高い值を示した。

母牛の TP 濃度は、虚弱群 ( 4 週間前 $7.3 \pm 0.5 \mathrm{~g} / \mathrm{dl}$ 、 2 週間前 $7.5 \pm 0.2 \mathrm{~g} / \mathrm{dl})$ と死亡群 $(7.5 \pm 0.7 \mathrm{~g} / \mathrm{dl}$ 、

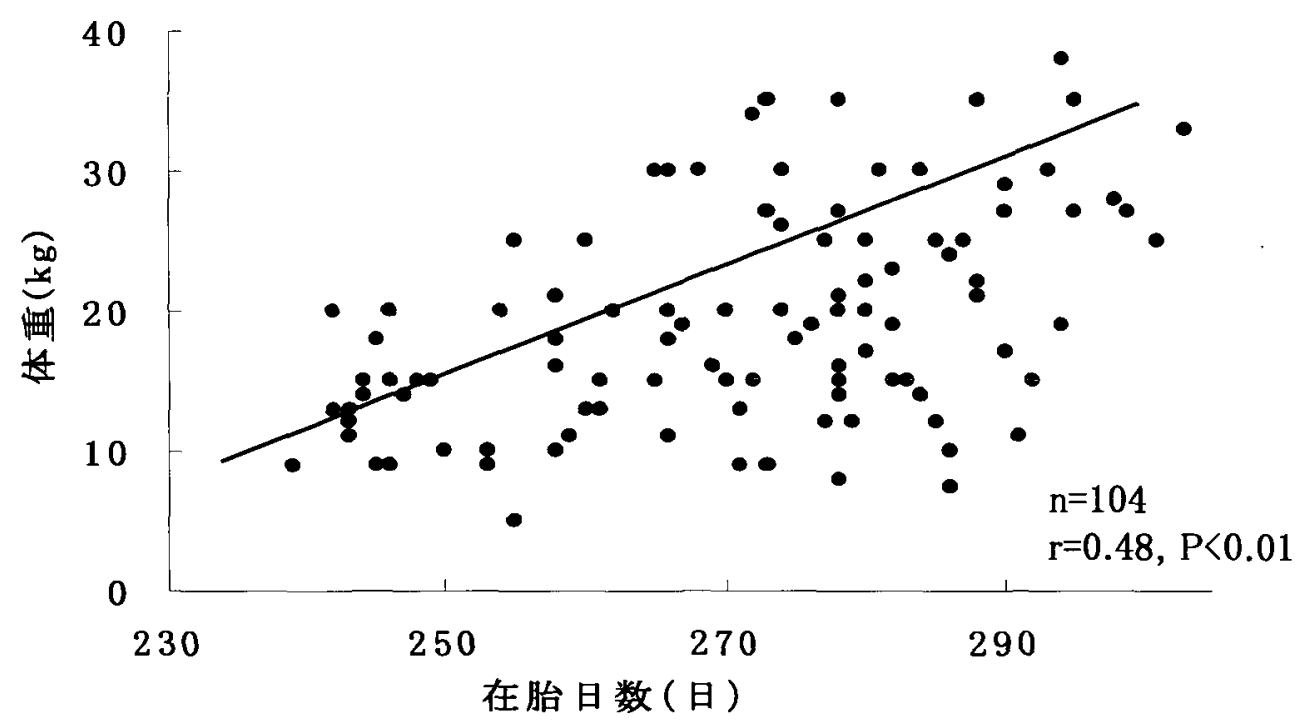

図 1。原因不明の死産例における在胎期間と胎子体重

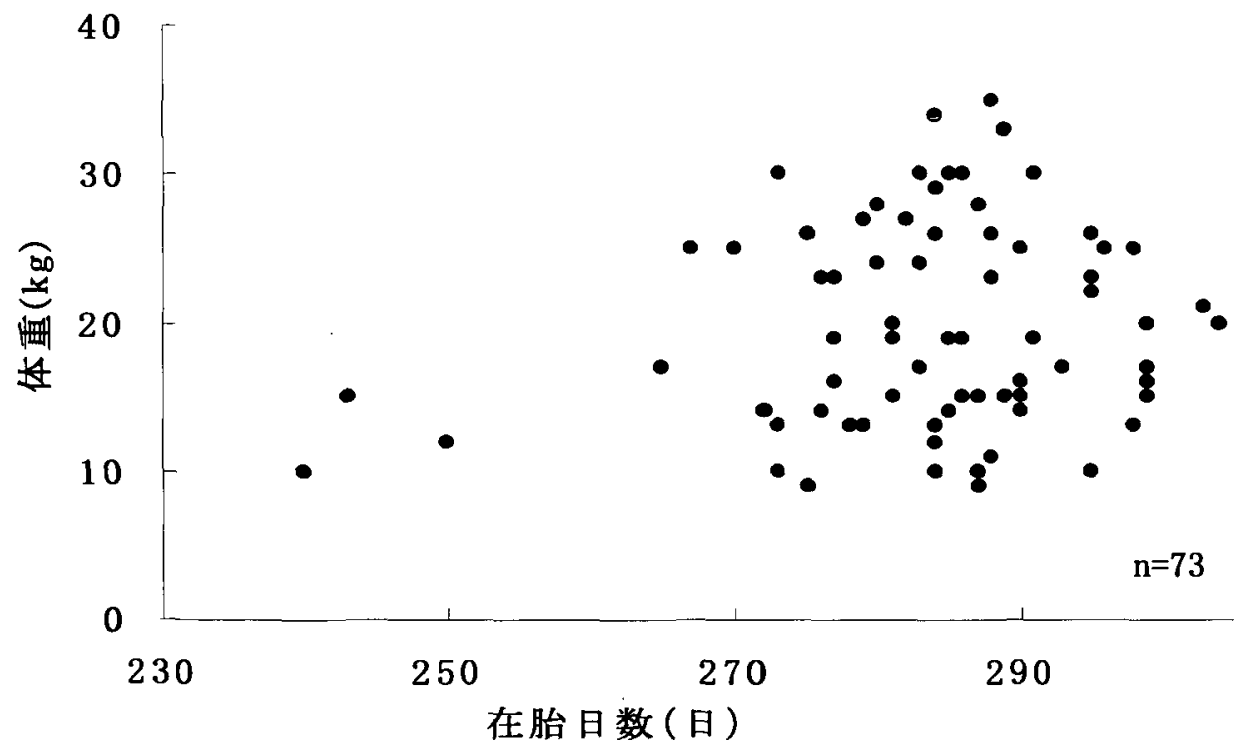

図 2．新生子虚弱による死亡例の在胎期間と出生時体重 
$7.3 \pm 0.6 \mathrm{~g} / \mathrm{dl})$ では、正常群 $(7.0 \pm 0.6 \mathrm{~g} / \mathrm{dl} 、 6.9 \pm$ $0.6 \mathrm{~g} / \mathrm{dl})$ に比べいずれの時期も高かった $(\mathrm{P}<0.05) 。$ 子牛の $\mathrm{TP}$ 濃度は死亡群では $3.5 \pm 0.4 \mathrm{~g} / \mathrm{dl}$ であり、正 常群の $4.2 \pm 0.6 \mathrm{~g} / \mathrm{d} 1$ に比べて低い值を示した（P< $0.01) 。 母$ 牛における分婏予定4週間前の T-Cho 濃度は、 死亡群では145.2 $230.1 \mathrm{mg} / \mathrm{d}$ であり、正常群の119.1土 $25.3 \mathrm{mg} / \mathrm{d} 1$ に比べて高い值を示した $(\mathrm{P}<0.05)$ 。しし、 子牛の T-Cho 濃度は各群とも $20 \mathrm{mg} / \mathrm{dl}$ 前後であり、差 は認められなかった。母牛の NEFA 濃度は、正常群で は 4 週間前と 2 週間前にそれぞれ $163 \pm 77 \mu \mathrm{mol} / 1$ と $163 \pm 66 \mu \mathrm{mol} / 10$ 值を示したが、虚弱群では 4 週間 前に $107 \pm 35 \mu \mathrm{mol} / 1$ と低值であり、2 週間前には 142 $\pm 38 \mu \mathrm{mol} / 1$ に増加を示した $(\mathrm{P}<0.05)$ 。死亡群では 4 週間前と 2 週間前にそれぞれ $108 \pm 47 \mu \mathrm{mol} / \mathrm{l} 、 116$ $\pm 70 \mu \mathrm{mol} / \mathrm{l}$ と低值であった。子牛の NEFA濃度は、 死亡群では1016 $\pm 167 \mu \mathrm{mol} / \mathrm{l}$ であり、正常群の302 $337 \mu \mathrm{mol} / 1$ および早産群の $313 \pm 230 \mu \mathrm{mol} / 1$ に比べ 高い值を示した $(\mathrm{P}<0.01)$ 。子牛の血糖値は正常群で

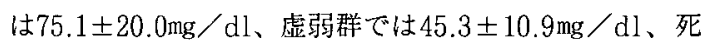
亡群では $28.3 \pm 10.3 \mathrm{mg} / \mathrm{dl}$ 扔よび早産群では
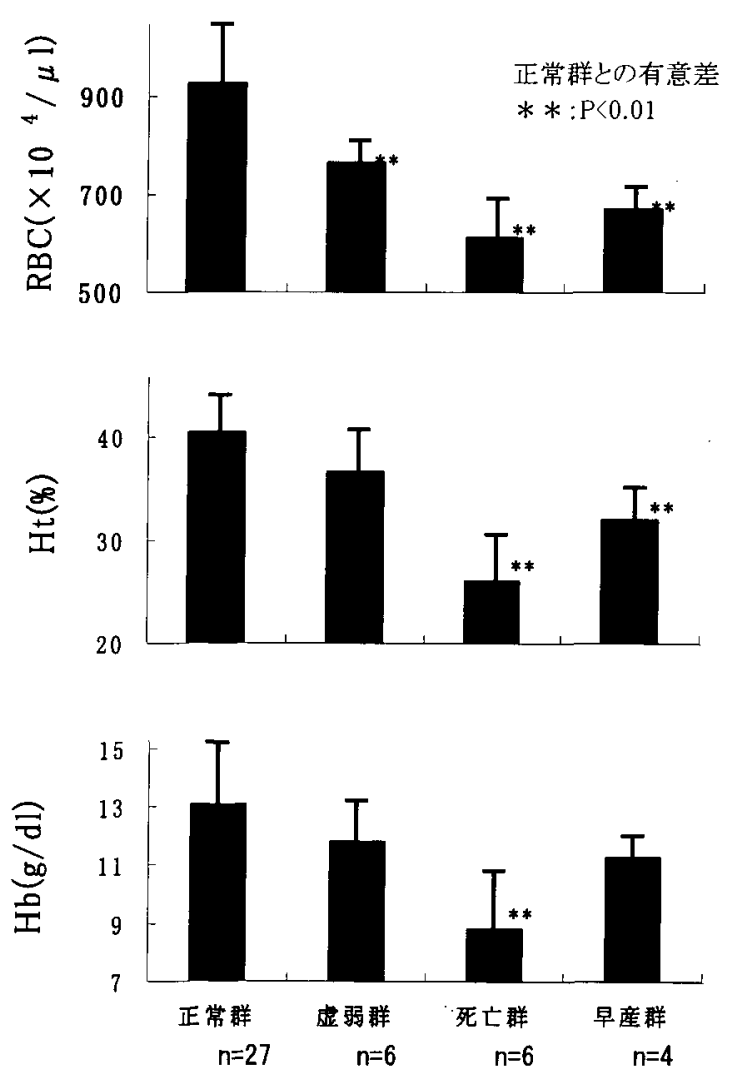

図 3. 出生子牛に扩ける赤血球系の測定值
$38.8 \pm 19.2 \mathrm{mg} / \mathrm{d} 1$ であり、正常群に比べ他の 3 群はいず れも低い值を示し $(\mathrm{P}<0.01) 、 と く に$ 死亡群は虚弱群 よりもさらに低い值であった $(\mathrm{P}<0.01)$ 。子牛15頭 （正常群12頭、虚弱群 1 頭、死亡群 2 頭）の血清鉄（ $\mathrm{Fe}$ ) 濃度と生時体重の間に正の相関 $(\mathrm{r}=0.64 、 \mathrm{P}<0.01)$ が みられたが、母子間の相関はなかった $(\mathrm{r}=0.37)$ 。

4 ) 死亡子牛の病理学的所見: 死亡した虚弱子牛 6 例中 3 例では皮膚が乾燥感を呈し、筋肉の退色が認められ、 2 例で胸腺の低形成が認められたが、内臓諸器官におい てはいずれの例も著変は認められなかった。骨喵は、4 例で赤色骾が萎縮し、骨髓造血細胞巣の著しい低形成像 が観察された。

以上の結果、虚弱子牛では赤血球系の值か著しく低く、 胎子期の造血機序に障害があった可能性が示唆された。 死亡例は治瘉例に比較して赤血球系の值がさらに低かっ たことから、この筫血の程度が虚弱子牛の予後に大きく 関係したと考えられた。死亡した虚弱子牛では 6 例中 4 例で骨䯣低形成の所見が観察され、骨䯣における造血機 能の未発達が、致命的な貧血をもたらしたものと考えら れた。

虚弱子牛を分婏した母牛では、妊娠末期の BCSが正 常群に比べて有意に高く、栄養状態は良好と考えられた。 Ht 值、T-Cho 濃度およびNEFA 濃度などから、虚弱 子牛を分婏した母牛では、妊娠末期に扔ける胎子の増体 [11] が少なく、栄養の消耗も少なかったものと考えら れた。

\section{4. 娃娠末期における胎子一胎盤機能と新生子虚弱}

新生子虚弱の発生に関わる要因として、胎子発育障害 と胎盤機能との関連性を明らかにすることを目的に、黒 毛和種牛 54 頭を用い、妊娠末期における血清中の胎子一 胎盤系機能に関与するステロイドホルモン濃度を測定し た $[6]$ 。

供試牛の産子は、体重が20kgを越えたもの（正常体重 子群）は41頭であり、20kg以下であったもの（低体重子 群）は13頭であった。低体重子群では、5頭は体重が低 いにもかかわらず活力があり、起立の介助や人工授乳な どの介護を必要としなかったが、他の 8 頭は出生後24時 間を経過しても自力で起立や吸乳ができない虚弱例であっ た。

1) 血清中ステロイド濃度の推移と子牛の出生時体重お よび活力との関係

(1)血清中 $\mathrm{P} 、 \mathrm{E}_{1}$ および $\mathrm{E}_{2}$ 濃度: 正常体重子群および低 体重子群における血中 $\mathrm{P} 、 \mathrm{E}_{1}$ および $\mathrm{E}_{2}$ 濃度の推移をみ 
たところ、AI 後257日から271日にか计て、両群ともに $\mathrm{P}$ 濃度には減少傾向がみられ、両群の $\mathrm{P}$ 濃度には差が 認められなかった。 $\mathrm{E}_{1}$ および $\mathrm{E}_{2}$ 濃度は、両群ともに上 昇を認めた $(\mathrm{P}<0.01)$ 。

(2)血清中 $\mathrm{E}_{1} \mathrm{~S}$ 溸度: $\mathrm{E}_{1} \mathrm{~S}$ 濃度と子牛の出生時体重との 間には、妊娠257日、271日ともに、正の相関が認められ た $(P<0.01)$ 。 $E_{1} S$ 濃度は、いずれの時期も正常体重 子群が低体重子群に比心゙高かった（P<0.01）。また、 妊娠257日から271日にかけて、正常体重子群では $E_{1} S$ 濃度の上昇が認如られた（ $\mathrm{P}<0.05 ） の に$ 対し、低体重 子群全体の E I S 濃度は低い值のまま推移した。さらに、 低体重子群の中で、体重が低いながら活力のある健康な 子牛を分婏した 5 頭と、虚弱な子牛を分婏した 8 頭の $\mathrm{E}_{1} \mathrm{~S}$ 濃度を比較したところ、前者では妊娠257日から 271日にかけて全例で $\mathrm{E}_{1} \mathrm{~S}$ 濃度が上昇したのに対し、後 者では 8 頭のうち 4 頭では $\mathrm{E}_{1} \mathrm{~S}$ 濃度の減少がみられ、 平均值は低い值で推移した。虚弱子牛分娩例の妊娠 271 日における $\mathrm{E}_{1} \mathrm{~S}$ 濃度は、健康子牛分婏例に比べ有意に 低かった $(\mathrm{P}<0.01)$ (図 4$)$ 。

2 ) 血清中 $\mathrm{E}_{1} \mathrm{~S}$ 濃度と血統の関倸: M (6 頭: $4.5 \pm 2.5$ $\mathrm{ng} / \mathrm{ml} 、 5.1 \pm 2.9 \mathrm{ng} / \mathrm{ml}$ )、Y ( 4 頭 : $5.9 \pm 1.2 \mathrm{ng} /$ $\mathrm{ml} 、 6.6 \pm 0.6 \mathrm{ng} / \mathrm{ml}) 、 \mathrm{O}$ (11頭: $5.3 \pm 2.1 \mathrm{ng} / \mathrm{ml}$ 、 $5.9 \pm 2.0 \mathrm{ng} / \mathrm{ml})$ を交配した母牛の $\mathrm{E}_{1} \mathrm{~S}$ 濃度は、その



$\mathrm{ml}$ と $10.7 \pm 4.1 \mathrm{ng} / \mathrm{ml})$ に比べて低かった（P<0.01）。 以上の成續加、 $\mathrm{E}_{1} \mathrm{~S}$ 濃度は出生子牛の体重と正の 相関を示し、妊娠末期の胎子の発育程度を推定する指標 のひとつとなり得ることが示唆された。 $\mathrm{E}_{1} \mathrm{~S}$ は、 $\mathrm{E}_{1}$ が 硫酸とエステル結合した抱合型エストロジェンで、その 血中濃度は胎子の発育にともなって上昇すること [12] が知られている。 $\mathrm{E}_{1} \mathrm{~S}$ 濃度とその前駆物質の $\mathrm{E}_{1}$ 濃度と の間では有意な相関がみられないことから、硫酸とのエ ステル結合過程が胎盤の機能を強く反映している可能性 が高いと考えられる。虚弱新生子では胎子期に扔ける母 体内発育遲延（IUGR）が認められ、胎子期の造血機能 障害㧍よび胎子一胎盤機能の低下によって起こることが 示唆された。

\section{5. 虚弱子牛の哺育期における低栄養と貧血の病態}

黒毛和種虚弱子牛13頭と正常子牛31頭について、出生 後経日的に血液性状を調べるとともに体重の測定を行っ た。虚弱子牛の生時体重は正常子牛より低く、生後 300 日前後で子牛市場に出荷されるまでの間の增体量 （DG）も低かった $(\mathrm{P}<0.01)$ 。虚弱子牛では、生後28 日まで赤血球系の測定值が正常子牛に比べ低く、造血障 害が疑われた。この貧血に関わる因子として、血清エリ スロポエチン、血清 $\mathrm{Fe}$ 濃度、母牛乳汁中の $\mathrm{Fe}$ 濃度お よび骨㓱液を調べたところ、血清エリスロポエチン濃度

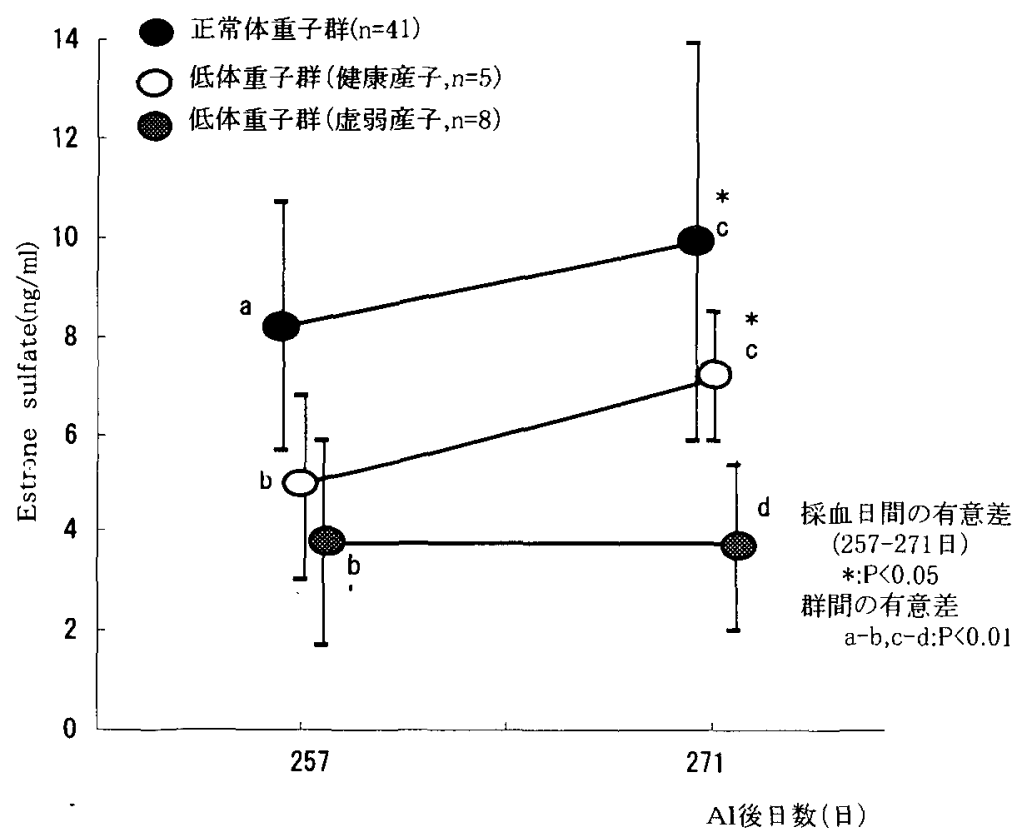

図 4. 黒毛和種牛の妊娠末期における血清中エストロンサルフェート浱度の 推移と出生子牛の体重（平均土標準偏差） 
は生後 7～14日に正常子牛と同様の上昇を示したが、血 清 Fe 濃度は正常子牛に比べ低く、骨䯣中の造血細胞数 は少なかった。

また、虚弱子牛においては出生直後の NEFA が正常 子牛より高く、出生翌日にBUNの上昇が認められたこ とから、体脂肪や体タンパク質動貝の充進が推察された。 さらに、虚弱子牛は出生翌日の $\gamma-$ GTP の測定值が正常 子牛より低く、グロブリン量も生後21日まで少ないこと から、初乳の恸取量または初乳成分の吸収量が正常子牛 より少ないことが推察された。

以上より、虚弱子牛では発育障害が認められ、正常子 牛よりも発育が著しく遅延すること、この発育障害の原 因としては低血糖や低タンパク血症などの低栄養および 胎子期の造血機能障害や鉄の供給不足などに起因する筫 血があげられることが示唆された。虚弱子牛に対しては エネルギー補給や鉄をはじめとする造血因子の投与を行 うとともに、感染症予防のための衛生的な管理が必要で あると考えられた。

\section{6. 新生子虚弱に対する高張ブドウ糖液および鉄剤経口 投与の効果}

黒毛和種における虚弱新生子の出生直後の低血糖を治 療する目的で高張ブドウ糖の経口投与を実施した [9]。 また、哺育期の貧血に対してペプチド鉄投与を実施し [7]、これらの治療効果について検討した。

1) 高張ブドウ糖液の経口投与: 出生後自力で起立吸乳 できなかった虚弱子牛14頭のうち、6頭に対して、25\% ブドウ糖液を体重 $1 \mathrm{~kg}$ あたり $10 \mathrm{ml}$ 経口投与した。これ らの子牛は、同量の初乳のみを投与した虚弱子牛 6 頭に 比べ、起立までの時間が明らかに短く $(\mathrm{P}<0.05)$ 、吸 乳行動を速やかに開始した頭数も多かった。また、25\% ブドウ糖液を $2.5 \mathrm{ml} / \mathrm{kg}$ 静脈内に投与した別の虚弱子牛 2 頭でも、ブドウ糖を経口投与した子牛と同様の症状改 善がみられた。

ブドウ糖を経口投与した子牛 3 頭と静脈内に投与した 2 頭について、投与 30 分後、60分後挹よび24時間後に血 糖值および血清中インスリン濃度を測定したところ、血 糖值は 5 頭とも 30 分後には上昇が認められ、60分後には 投与前の約 2 倍の值を示した。また、インスリン濃度は 血糖値とほほ同様の推移を示した。

2 ) 鉄剂の経口投与：虚弱子牛11頭中 4 頭、正常子牛 29 頭中14頭に対して、乾物中鉄含有量 $10 \%$ のペプチド鉄剂 を 1 日あたり $10 \mathrm{~g} 、 28$ 日間経口的に投与した。これらの 子牛は、経日的に赤血球系の值測定するとともに、子
牛市場出荷時の体重から DG 算出し、投与しなかっ た虚弱子牛 7 頭㧍よび正常子牛15頭（対照群）と比較し た。

投与群の DGは、虚弱子牛および正常子牛ともに、 対照群に比べ高い傾向がみられたが、有意差はなかった。 赤血球系の測定值は、投与群では生後 7 日から差を認め、 対照群に比べ高い值を示した。また、正常子牛において も生後14日から貧血の改善効果が認められた。

以上より、出生直後の虚弱子牛は投与したブドウ糖を 利用することが可能で、高張ブドウ糖の経口投与は、虚 弱子牛の低血糖を速やかに改善することが示惨された。 また、ペプチド鉄の経口投与は、哺育期に扔ける虚弱子 牛の筫血扩よび正常子牛の生理的䝷血に対して有効な治 療方法と考えられた。

\section{7. 謝辞}

本研究にあたり終始ご指導いただいた酪農学園大学獣 医臨床繁殖学教室、中尾敏彦教授に深謝します。

\section{8. 文献}

1. Blood, D. C., Henderson, J. A. and Radostits, O. M (1981): 臨床獣医学 I (臼井和哉, 本好茂一監訳)。63-80。文永堂。東京。

2. Cain, D. V. and Dennis, S. M. (1987) : Peri natal calf mortality. Agric, Practice. $8: 11-16$.

3. Kasari, T. R. (1989): Weakness in neonatal calves associated with dystocia. Agric. Practice. 10:19-25.

4. 野口 等 (1992): 和牛の胎子死㧍よび新生子死の 実態とフィールドでの対応. 獣畜新報 $45:$ 527-530. 5. 小形芳美, 阿部浩之, 三澤 隆, 高橋浩吉, 伴 顕, 加藤敏英, 酒井淳一 (1995): 黑毛和種子牛における 周应期死亡の原因と出生時体重. J. Reprod. Dev. $41: \mathrm{j} 77-\mathrm{j} 81$.

6. 小形芳美, 高橋浩吉, 阿部浩之, 三澤 隆, 加藤敏 英, 酒井淳一, 大崎和栄, 南保泰雄, 中田 健, 中尾 敏彦 (1996): 黑毛和種牛の妊娠末期における血清中 性ステロイド濃度と出生子牛の体重および活力。J Reprod. Deu. 42 : j85-j89.

7. 小形芳美, 高橋浩吉, 阿部浩之, 三澤 隆, 河野, 酒井淳一 (1992)：黑毛和種新生子牛における筫血の 病態とその対策. 家畜診療 $346: 29-37$.

8. 小形芳美, 高橋浩吉, 阿部浩之, 三澤 隆, 漆山芳 郎, 加藤敏英, 酒井淳一（1996）：黒毛和種に招ける 
虚弱子牛の血液性状および母牛との関係. 日獸会誌 $50: 253-257$.

9. 小形芳美, 高橋浩吉, 阿部浩之, 三澤 隆, 淥山芳 郎, 酒井淳一 (1997)：黑毛和種牛の虚弱新生子に对 する高張ブドウ糖液経口投与の効果．獣苗新報． 50 ： 115-119.

10. 小形芳美, 高橋浩吉, 漆山芳郎, 佐藤 光, 酒井淳 一 (1997): 黑毛和種における母体内発育遅延虚弱子 牛と血統の関連. 日獣会誌 $50: 271-273$.

11. 岡野 彰 (1994)：黑毛和種雌ウシに扔ける生涯子 ウシ生産性ならびに胎子発育に関する研究。J. Reprod Dev. 40 : 117-129.

12. Robertson, H. A. and King, G. J. (1979): Conjugated and unconjugated oestrogens in fetal and maternal fluids of the cow throughout pregnancy. J. Reprod. Fert. 55 : 463-470.

13. 高橋浩吉, 小形芳美, 酒井淳一 (1990): 和牛子牛 の死亡事故とその要因調查一虚弱子牛の血液学的なら びに病理学的所見を中心に一, 家畜診療 $323: 21-27$.

14. Wildman, E. E., Jones, G. M., Wagner, P. E., Boman, R. L., Troutt, JR. H. F. and Lesch, T. N (1982): A dairy cow body condition scoring system and its relationship to selected production. J. Dairy Sci. 65 : 495-501.

15. 山口浩介, 㐘川良男 (1990): 肉牛の胎児および子 牛の事故発生状況と特殊疾病、家畜診療 327:43-46.

16. Ogata, Y., Nakao, T., Takahashi, K., Misawa, T., Urushiyama, Y. and Sakai, J. (1999): Intrauterine growth retardation as a cause of perinatal mortality in Japanese Black beef calves. J. Vet. Med. A. 46 : 327-334. 